\title{
Campylobacter jejuni in Musca domestica: An examination of survival and transmission potential in light of the innate immune responses of the house flies
}

\author{
Gill, Carson; Bahrndorff, Simon; Lowenberger, Carl
}

Published in:

Journal of Insect Science

Link to article, DOI:

10.1111/1744-7917.12353

Publication date:

2017

Document Version

Peer reviewed version

Link back to DTU Orbit

Citation (APA):

Gill, C., Bahrndorff, S., \& Lowenberger, C. (2017). Campylobacter jejuni in Musca domestica: An examination of survival and transmission potential in light of the innate immune responses of the house flies. Journal of Insect Science, 24(4), 584-598. https://doi.org/10.1111/1744-7917.12353

\section{General rights}

Copyright and moral rights for the publications made accessible in the public portal are retained by the authors and/or other copyright owners and it is a condition of accessing publications that users recognise and abide by the legal requirements associated with these rights.

- Users may download and print one copy of any publication from the public portal for the purpose of private study or research.

- You may not further distribute the material or use it for any profit-making activity or commercial gain

- You may freely distribute the URL identifying the publication in the public portal 
Running title: Campylobacter transmission by house flies

Title for authors: C. Gill et al.

Correspondence: Carl Lowenberger, Department of Biological Sciences, Simon Fraser University, 8888 University Drive, Burnaby BC V5A 1S6 Canada. Tel: 1778782 3985; email: clowenbe@sfu.ca

\section{Original article}

Campylobacter jejuni in Musca domestica: An examination of survival and transmission potential in light of the innate immune responses of the house flies

Carson Gill ${ }^{1,}$ Simon Bahrndorff ${ }^{2,3}$, and Carl Lowenberger ${ }^{1 *}$

${ }^{1}$ Department of Biological Sciences, Simon Fraser University, 8888 University Drive, Burnaby BC, Canada, ${ }^{2}$ National Food Institute, Technical University of Denmark, 2800 Kongens Lyngby, Denmark, and ${ }^{3}$ Present address: Department of Chemistry and Bioscience, Aalborg University, 9220 Aalborg, Denmark

\section{Abstract}

The house fly, Musca domestica, has been implicated as a vector of Campylobacter spp., a major cause of human disease. Little is known whether house flies serve as biological amplifying hosts or mechanical vectors for Campylobacter jejuni. We investigated the period after $C$. jejuni had been ingested by house flies in which viable $C$. jejuni colonies could be isolated from whole bodies, the vomitus and the excreta of adult $M$. domestica and evaluated the activation of innate immune responses of house flies to ingested $C$. jejuni over time. $C$. jejuni could be cultured from infected houseflies soon after ingestion but no countable $C$. jejuni colonies were observed $>24$ hours postingestion. We detected viable $C$. jejuni in house fly vomitus and excreta up to 4 hours after ingestion, but no viable bacteria were detected $\geq 8$ hours. Suppression subtractive hybridization identified pathogen-induced gene expression in the intestinal tracts of adult house flies 4-24 hours after ingesting $C$. jejuni. We measured the expression of immune regulatory (thor, JNK, and spheroide) and effector (cecropin, diptericin, attacin, defensin and lysozyme) genes in C. jejuni-infected and -

This is an Accepted Article that has been peer-reviewed and approved for publication in the Insect Science but has yet to undergo copy-editing and proof correction. Please cite this article as doi: 10.1111/1744-7917.12353.

This article is protected by copyright. All rights reserved. 
uninfected house flies using quantitative real time PCR. Some house fly factor, or combination of factors, eliminates $C$. jejuni within 24 hours post-ingestion. Because $C$. jejuni is not amplified within the body of the housefly, this insect likely serves as a mechanical vector rather than as a true biological, amplifying vector for $C$. jejuni, and adds to our understanding of insect-pathogen interactions.

Keywords antimicrobial peptides, Campylobacter spp., Campylobacteriosis, house fly, innate immunity, Musca domestica, suppression subtractive hybridization (SSH), vector

\section{Introduction}

Campylobacteriosis is a severe gastroenteric human disease caused by bacteria of the genus Campylobacter, and is one of the most common and widespread food-borne infections globally and is an emerging or re-emerging pathogen that contributes to acute and chronic gastrointestinal disease (Kaakoush et al., 2015a,b). In the European Union > 220000 cases were confirmed in 2011 (ECDC, 2013) but estimates suggest that only a small percentage of all cases are reported; the true incidence of campylobacteriosis is approximately nine million cases per year (EFSA, 2011) and an estimated $\$ 8.0$ billion are spent annually in the USA on Campylobacter spp. infections and associated sequelae in humans (Buzby et al., 1997). In addition to gastrointestinal disease Campylobacter sp. has been linked to inflammatory bowel disease, colorectal cancer (Man, 2011) and autoimmune conditions such as Guillain-Barré syndrome and Miller Fisher syndrome (Kaakoush et al., 2015a).

The primary source of Campylobacter spp. in human infections is contaminated food sources, especially contaminated poultry products, which cause more than $50 \%$ of all cases (EFSA, 2014; WHO, 2013). The infection of poultry with Campylobacter spp. primarily occurs through environmental contamination of poultry facilities (van de Giessen et al., 1992; Jacobs-Reitsma et al., 1995; Nayduch et al., 2013). Numerous sources have been implicated in the introduction of Campylobacter spp. into, and subsequently throughout, poultry facilities including contaminated water, feed, rodents and insects (WHO, 2013) and among these, house flies (Musca domestica) are considered to be major vectors (Rosef \& Kapperud, 1983; Shane et al., 1985; Hald et al., 2004; Hald et al., 2008 ). The prevalence of Campylobacter spp. in poultry correlates with high numbers of house flies during the summer months (Skovgård \& Jespersen, 2000; Nichols, 2005) and house flies can disperse indiscriminately over large distances, transporting bacteria between distant farms (Kjærsgaard et al., 2015; Nazni et al., 2005). Physically preventing house flies from entering poultry facilities, by using fly screens, can reduce substantially the prevalence of Campylobacter jejuni in poultry facilities (Hald et al., 2007; Bahrndorff et al., 2013).

This article is protected by copyright. All rights reserved. 
The association between house flies and bacteria, including Campylobacter spp., is not surprising because house flies forage, breed, and develop in vast numbers in animal manure and human excrement where bacteria are abundant (Pell, 1997; Guan \& Holley, 2003; Szalanski et al., 2004; Klein et al., 2010; Joyner et al., 2013; Fleming et al., 2014). Foraging flies, therefore, may have their bodies contaminated with Campylobacter spp. and they also ingest large numbers of bacteria (Shane et al., 1985; Petridis et al., 2006). House flies continually regurgitate to liquefy, mix, and digest their food through extracorporeal digestion, and defaecate remains of previous meals, potentially disseminating Campylobacter spp. either from the mouth (vomitus) or anus (excreta) (Hewitt, 1914; Joyner et al., 2013). Although other microbial pathogens multiply and persist within the alimentary tract of adult flies (Kobayashi et al., 1999; Sasaki et al., 2000; Joyner et al., 2013; Fleming et al., 2014), C. jejuni is thought to survive for relatively short periods in house flies, usually < 24 hours (Bahrndorff et al., 2014c; Gill, 2014; Skovgård et al., 2011).

Little is known of the impact of ingested microorganisms on house flies, but they, like all invertebrates, possess an effective innate immune system to eliminate potential pathogens. Pattern recognition receptors (PRRs) (Medzhitov \& Janeway, 1997) recognize conserved pathogenassociated molecular patterns (PAMPs) on the outer surfaces of pathogens, and activate components of the humoral and cellular responses via multiple signalling cascades, including the Toll, Imd, RNAi, JNK and JAK-STAT pathways (Boutros et al., 2002, Leclerc \& Reichhart, 2004, Tsakas \& Marmaras, 2010). This response culminates in numerous effector mechanisms, including the expression of multiple antimicrobial peptides (AMPs) that target and kill microorganisms (Lowenberger et al., 1995; Bulet et al., 1999; Lowenberger et al., 1999; Lowenberger, 2001; Lopez et al., 2003; Boulanger et al., 2004, Boulanger et al., 2006; Ursic-Bedoya \& Lowenberger, 2007; UrsicBedoya et al., 2011). While the majority of immune responses are expressed in the hemocoel of insects (Lowenberger et al., 1995; Lowenberger, 2001), several AMPs also are expressed in the insect alimentary tract to prevent the overproliferation of non-desirable symbionts (Lowenberger et al., 1995; Ursic-Bedoya \& Lowenberger, 2007; Ursic-Bedoya et al., 2011).

We demonstrated previously that $C$. jejuni ingested by house fly larvae survive in large numbers through moults into pupae, but not into the adult stage (Bahrndorff et al., 2014b) and that C. jejuni ingested by adult house flies does not survive for periods $>24$ hours (Skovgård et al., 2011). Whether this is due to the bacteria being digested or whether ingested $C$. jejuni elicit an immune response by adult house flies is unknown. This is similar to the fate of Staphylococcus aureus in house flies (Nayduch et al., 2013) but differs from other bacteria that replicate within the house fly (Nayduch et al., 2002; McGaughey \& Nayduch, 2009). Pseudomonas aeruginosa, for example, showed an initial decline and subsequently an increase in bacterial numbers (Joyner et al., 2013). The relationship between bacteria and house flies, therefore, may be species specific and warrants further study on the specificity of the molecular interactions between host and pathogen that eliminate or modulate pathogen numbers (Lopez et al., 2003; Ursic-Bedoya et al., 2011). There are conflicting reports on the presence, absence, and expression levels of AMPs in house flies that have ingested different strains of bacteria (Liang et al., 2006; Wang et al., 2006; Dang et al., 2010; , Joyner

This article is protected by copyright. All rights reserved. 
et al., 2013; Nayduch \& Joyner, 2013; Fleming et al., 2014), and with the recently published genome of M. domestica available, no doubt other AMPs will be identified (Scott et al., 2014).

In this study, we determined the temporal fate of ingested $C$. jejuni in house flies by determining the period during which viable bacteria could be cultivated from the whole bodies, vomitus, and faeces of infected house flies. We used suppression subtractive hybridization (SSH) to identify and characterize differentially expressed genes in the GI tracts of house flies in response to ingested $C$. jejuni. The viability of $C$. jejuni was correlated with expression levels of immune-related genes, effectors and regulators, in the GI tracts of adult house flies.

\section{Materials and methods}

\section{Insect colony maintenance}

A colony of $M$. domestica, originally purchased from Beneficial Insectary Inc. (Redding, CA, USA), has been maintained in the insectary at Simon Fraser University since 2012. Adult individuals were reared in the laboratory at $25{ }^{\circ} \mathrm{C}$ and $80 \% \mathrm{RH}$ with a photoperiod of $16: 8$ (Light:Dark). The house flies were fed on milk powder, sugar, and tap water.

\section{Cultivation of Campylobacter jejuni for infection of house flies}

A green fluorescent protein (GFP) labeled C. jejuni strain RM1221 (pWM1007) (Miller et al., 2000) was used to infect house flies. Bacterial cultures were reconstituted from brain-heart-infusion glycerol stocks and grown overnight on blood-agar plates incubated at $42{ }^{\circ} \mathrm{C}$ in a microaerobic atmosphere generated using GasPak ${ }^{\mathrm{TM}}$ EZ Campy Container System Sachets (BD, Sparks, MD, USA) in a Brewer's jar. Subsequently, bacteria were collected from the plates and resuspended in sterile $0.9 \% \mathrm{NaCl}$ at an optical density (OD) of 0.6 at $620 \mathrm{~nm}$ (approximately $10^{9}$ colony forming units $(\mathrm{CFU}) / \mathrm{mL}$ ). The presence of $C$. jejuni was confirmed using fluorescent microscopy and the suspensions were kept on wet ice throughout the experiments. The concentration of $C$. jejuni in the saline solution was determined before and after exposure by plating serial dilutions and counting bacterial colonies to ensure all flies were exposed to approximately the same number of bacteria.

\section{Exposure of adult flies to C. jejuni}

The protocol to expose adult house flies to $C$. jejuni was modified after Skovgard et al. (2011). Briefly, 5 day $\pm 24 \mathrm{~h}$ old male house flies that had been starved overnight were anesthetized with $\mathrm{CO}_{2}$ and subsequently fixed individually inside a sterile pipette tip that allowed the head and proboscis to protrude. A pipette tip containing $1 \mu \mathrm{L}$ of the $C$. jejuni suspension was presented as a drop to each fly. Flies that declined or stopped feeding were removed from the study. After ingestion, house flies were maintained individually in sterile $50 \mathrm{ml}$ Falcon tubes (BD, Sparks, MD, USA) that were covered with a foam stopper. All house flies had access to an $8 \%$ sucrose solution $a d$

This article is protected by copyright. All rights reserved. 
libitum. The control flies were subject to the same exposure protocols, but ingested $1 \mu \mathrm{L}$ of sterile $0.9 \%$ saline solution containing no bacteria.

\section{Campylobacter jejuni CFU determinations}

Ten adult house flies ( 5 replicates of two individual flies per replicate per time point) were collected at 4, 8, 12, and $24 \mathrm{~h}$ after exposure to $C$. jejuni or saline solution to estimate numbers of $C$. jejuni. Individual house flies were weighed, diluted $1: 10 \mathrm{w} / \mathrm{v}$ in $0.9 \%$ saline and homogenized using a mortar and pestle. Bacterial numbers were determined by plating ten-fold serial dilutions of the sample in a $0.9 \%$ saline solution onto Campylobacter spp. selective modified charcoal-cefoperazonedeoxycholate agar (mCCDA; CM 739 plus SR155E, Oxoid Ltd., Basingstoke, Hampshire, UK) plates. Plates were incubated microaerobically at $42^{\circ} \mathrm{C}$ for 48 hours before the $C$. jejuni colonies on the plates were counted and the number of bacteria per sample were estimated. These plates with bacteria were visualized using fluorescent microscopy (Zeiss Canada LTD., Toronto, ON, Canada) to confirm that the bacteria were GFP labeled $C$. jejuni.

\section{Visualization of C. jejuni in the vomitus of infected flies}

Four $C$. jejuni-exposed flies per time point from each of 2 replicates were sampled at $<1,2$, $4,8,12$, and $24 \mathrm{~h}$ following ingestion and evaluated for the presence of GFP-labeled $C$. jejuni in the regurgitate. Houseflies can be induced to regurgitate by applying light pressure to the body while holding the flies. Individual flies were placed at $4^{\circ} \mathrm{C}$ for approximately 5 minutes to reduce activity. Chilled flies were grasped with a pair of sterile forceps, the abdomen was squeezed lightly and the mouth parts were placed on a microscope slide upon which they regurgitated. The vomitus spot was marked, covered with a cover slip, and examined immediately at 1000x under oil immersion using fluorescent microscopy (Zeiss Canada LTD., Toronto, ON, Canada). The vomitus of control flies was visualized at each time point and the original solution used for infection of the flies was visualized as a positive control.

\section{Retention of viable C. jejuni in the vomitus and excreta of infected flies}

In order to evaluate the presence of GFP-labeled $C$. jejuni in the vomitus and excreta of houseflies, houseflies were exposed to $C$. jejuni as described above and then were placed individually in $1.5 \mathrm{~mL}$ Eppendorf tubes with a foam stopper and access to $8 \%$ sucrose solution ad libitum. Two replicates of five infected and control flies per time point were removed from their individual microcentrifuge tubes at $<1,2,4,8,12$, and $24 \mathrm{~h}$ after exposure. Tubes were rinsed with $100 \mu \mathrm{L}$ of $0.9 \% \mathrm{NaCl}$, vortexed, and three aliquots $(20 \mu \mathrm{L})$ of each were plated onto mCCDA plates, incubated microaerobically at $42^{\circ} \mathrm{C}$ for 48 hours, and evaluated for the growth of C. jejuni as described above

This article is protected by copyright. All rights reserved. 
House flies were exposed, as described above, to a suspension of GFP-labeled C. jejuni with a concentration of approximately $2.1 \times 10^{9} \mathrm{CFU} / \mathrm{mL}$. The Gl tracts were dissected from 15 infected and control adult flies per time point at $4,8,12$, and $24 \mathrm{~h}$ following ingestion of $C$. jejuni for the first biological replicate and from 5 infected and 5 control flies per time point for the second and third biological replicates from 2, 4, 8, 12, and $24 \mathrm{~h}$ after ingestion of $C$. jejuni. Fewer flies were used in replicates 2 and 3 as the amount of RNA extracted was far more than required. Dissected tissues, including the intestine, Malpighian tubules, salivary glands and crop, were stored at $-80^{\circ} \mathrm{C}$. Total RNA extraction from the GI tracts was performed using TRI Reagent RNA Isolation Reagent (SigmaAldrich, St. Louis, MO, USA) according to manufacturer's specifications. Total RNA was quantified using a NanoDrop $2000 \mathrm{C}$ (Thermo Fisher Scientific, Wilmington, DE, USA). mRNA was isolated using Purist poly-A micro-spin columns (Ambion, Austin, TX, USA) according to the manufacturer's protocols. Subsequently $0.5 \mu \mathrm{g}$ of mRNA from time points $4,8,12$, and $24 \mathrm{~h}$ post ingestion were pooled (total of $2 \mu \mathrm{g}$ ) separately for positive (infected) and negative (non-infected) samples.

\section{Subtractive library construction and efficiency analysis}

A subtractive library was generated from the pooled mRNA samples using the PCR-select cDNA Subtraction Kit following the manufacture's recommendations (Clontech, Palo Alto, CA, USA) and as described previously (Ursic-Bedoya \& Lowenberger, 2007; Barón et al., 2010). Briefly, the 2 $\mu \mathrm{g}$ of mRNA was used in first and second strand cDNA synthesis following the manufacturer's protocols. Subsequently the cDNAs were digested with RSA I enzyme and specific adaptors were ligated to both ends of the CDNAs, followed by subtractive hybridization, and PCR amplification with specific adaptor primers as described in the protocols. In SSH amplification of hybrids corresponding to common sequences is suppressed, yielding a library enriched for differentially expressed sequences in the $C$. jejuni-exposed house flies. The efficiency of the subtraction process was estimated by comparing the abundance of the constitutively expressed genes, $b$-actin and GAPDH, before and after subtraction as described previously (Ursic-Bedoya \& Lowenberger, 2007; Barón et al., 2010). The primers for 6 -actin and GAPDH amplification, shown in Table 1, were used in standard PCR reactions under the following conditions: $94^{\circ} \mathrm{C}$ for $1 \mathrm{~min}$, followed by 33 cycles of $94^{\circ} \mathrm{C}$ for $10 \mathrm{~s}$, $60^{\circ} \mathrm{C}$ for $10 \mathrm{~s}$ and $72^{\circ} \mathrm{C}$ for $30 \mathrm{~s}$. Five microliter aliquots were removed from each reaction after 18 , 23,28 , and 33 cycles, examined by electrophoresis on a $2 \%$ agarose gel, and stained with Gel-Red to evaluate subtraction success.

\section{Cloning, plasmid isolation, DNA sequencing and database search}

An aliquot $(4 \mu \mathrm{L})$ of the PCR product from the subtracted library was ligated overnight at $4{ }^{\circ} \mathrm{C}$ into pGEM-T Easy plasmid vector (Promega, Madison, WI, USA), transformed by heat shock into Escherichia coli JM109 ultra competent cells (Promega, Madison, WI, USA), plated onto LB plates supplemented with $100 \mu \mathrm{g} / \mathrm{mL}$ carbenicillin, $80 \mu \mathrm{g} / \mathrm{mL} \mathrm{X-gal,} \mathrm{and} 0.5 \mathrm{mmol} / \mathrm{L}$ IPTG, and incubated overnight at $37^{\circ} \mathrm{C}$ as described (Ursic-Bedoya \& Lowenberger, 2007). Individual white colonies were screened using PCR to confirm the presence of an insert; colonies were resuspended individually in

This article is protected by copyright. All rights reserved. 
$10 \mu \mathrm{L} d \mathrm{dH}_{2} \mathrm{O}$ and $1 \mu \mathrm{L}$ of this solution was used in a standard PCR reaction using SP6 and T7 primers that flank the multiple cloning site in the vector and are used to estimate the size of cloned inserts. The conditions used were $96^{\circ} \mathrm{C}$ for $2 \mathrm{~min}$, followed by 40 cycles of $96^{\circ} \mathrm{C}$ for $10 \mathrm{~s}, 50^{\circ} \mathrm{C}$ for $10 \mathrm{~s}$, and $72^{\circ} \mathrm{C}$ for $30 \mathrm{~s}$. PCR products were size fractionated on $1 \%$ agarose gels and stained with Gel-Red to confirm the presence of, and estimate the size of, any insert. Positive colonies were grown overnight in $5 \mathrm{~mL}$ of LB medium with $5 \mu \mathrm{L}$ carbenicillin $(100 \mu \mathrm{g} / \mu \mathrm{L})$. Glycerol stocks of the overnight cultures $(100 \mu \mathrm{L})$ were aliquoted into 96 -well plates and stored at $-80 \circ \mathrm{C}$. Plates were sent to the Genome Sciences Centre, BC Cancer Agency (Vancouver, Canada) where each clone was sequenced.

Analysis of the sequence data, detection of open reading frames and sequence alignment, were performed using DNAstar modules Seqman, MegAlign, Editseq (DNAstar, Madison, WI, USA), and Clustal Omega [http://www.ebi.ac.uk/Tools/msa/ clustalo/]. Database search was performed using BLAST-X and BLAST-N against non-redundant databases at NCBI with default parameters. The best annotated BLAST-X match from the similarity search was retained and BLAST-N matches were only used when a BLAST-X search resulted in no sequence similarity with an Expect (E) value less than 0.1. We used the official Gene Ontology browser and search engine, AmiGO (Ashburner et al., 2000; Carbon et al., 2009), for a functional prediction of our ESTs (expressed sequence tags) and the BLAST Search annotation tool (BLASTX and/or BLASTP) of AmiGO to cluster the ESTs based on the biological process annotation when available. Novel ESTs were submitted to dbEST at the National Centre for Biotechnology Information (NCBI) and assigned accession nos. 78910768-78911127 [GenBank JZ545987-JZ546346] described in more detail in Table S1.

cDNA synthesis and Real Time Quantitative PCR (qRT-PCR)

We used qRT-PCR to evaluate the temporal expression of the differentially expressed genes identified through SSH. We used the RNA extracted at the different time points from the intestinal tracts of control or $C$. jejuni-exposed insects described above (4-24 h post ingestion in replicate 1 and 2-24 h in replicates 2 and 3). Total RNA was quantified using a NanoDrop 2000C (Thermo Fisher Scientific, Wilmington, DE, USA). cDNAs from each time point were synthesized with $5 \mu \mathrm{g}$ of total RNA using MMLV-RT (Promega, Madison, WI, USA) and a dT primer with a 5 ' extension (5'CGGGCAGTGAGCGCAACG $(T)_{14}-3$ ') as previously described (Lopez et al., 2003; Ursic-Bedoya et al., 2011).

We designed primers (Table 1) for use in qRT-PCR to compare the expression of select immune-related regulatory genes (spheroide, JNK, and thor), AMPs (defensin, cecropin, attacin, diptericin), a digestive enzyme (lysozyme) and housekeeping genes (b-actin and GAPDH) as previously described (Bahrndorff et al., 2014b; Gill, 2014). Amplicons generated with these primers were size-fractionated on 1\% agarose gels, bands were excised, purified (QIAquick Gel Extraction Kit (Qiagen, Netherlands), and sequenced using Big-Dye chemistry (Life Technologies, Carlsbad, CA, USA). The efficiencies of PCR amplification for each primer pair were determined as described (Livak \& Schmittgen, 2001; Schmittgen \& Livak, 2008; Bahrndorff et al., 2014b; Gill, 2014,).

This article is protected by copyright. All rights reserved. 
qRT-PCR was used to measure expression of the target mRNAs in cDNAs from infected and control fly GI tracts at different timepoints after ingesting saline or $C$. jejuni. All qRT-PCR reactions were performed on a Rotor-Gene 3000 (Corbett Research, Mortlake, NSW, Australia) using the PerfeCTa SYBR Green SuperMix (Quanta Biosciences, Gaithersburg, MD, USA). We used $1 \mu \mathrm{L}$ of cDNA with $12.5 \mu \mathrm{L}$ of SYBR Green SuperMix, $1 \mu \mathrm{L}$ (50 ng) of forward primer, and $1 \mu \mathrm{L}$ (50 ng) of reverse primer in $25 \mu \mathrm{L}$ reactions under the following conditions: $95^{\circ} \mathrm{C}$ for $2 \mathrm{~min}$, followed by 35 cycles of $95^{\circ} \mathrm{C}$ for $10 \mathrm{~s}, 55^{\circ} \mathrm{C}$ or $60^{\circ} \mathrm{C}$ for $15 \mathrm{~s}$, and $72^{\circ} \mathrm{C}$ for $30 \mathrm{~s}$. To ensure only a single product was amplified, a melt curve analysis was performed, and a non-template negative control was included for each primer set to check for primer-dimers and contamination in the reactions.

qRT-PCR results were analyzed using described methodologies (Livak \& Schmittgen, 2001; Schmittgen \& Livak, 2008). We normalized expression levels using the geometric mean (Vandesompele et al., 2002) of two internal controls ( $\beta$-actin and GAPDH) to generate $\triangle \mathrm{Ct}$ values(Vandesompele et al., 2002; Zhong et al., 2013). We compared gene expression between infected and control flies using $2^{-\Delta C t}{ }_{\text {Inf }} / 2^{-\Delta C t}$ con, with the results presented as fold changes using the control (non-exposed) flies as the second calibrator. In the graphs the levels expressed in the control flies are arbitrarily set to 1 and the levels in the exposed flies represent fold changes with respect to the control flies. The results are presented as the means and standard errors of gene expression from cDNAs generated from 2-3 independent biological replicates, and with each sample run in duplicate. Fold changes $>2$ are considered statistically significant.

\section{Results}

Temporal decline in C. jejuni following ingestion

The $C$. jejuni suspension used to infect the house flies was estimated to contain $2.1 \times 10^{9}$ $\mathrm{CFU} / \mathrm{mL}$. All pools of $2 \mathrm{C}$. jejuni-exposed flies sampled at 4 and $8 \mathrm{~h}$ after exposure were positive for $C$. jejuni, with a mean CFU/g of $1.90 \times 10^{6}$ and $5.08 \times 10^{5}$, respectively (Fig. 1). At $12 \mathrm{~h}$ post-exposure colonies were observed at dilutions down to $10^{-3}$ and at $24 \mathrm{~h}$ at $10^{-1}$, but individual colonies were not abnormal and were not discernible. All flies fed on saline alone were negative for $C$. jejuni.

\section{Visualization of Campylobacter jejuni in house fly vomitus}

The saline solution of GFP-labeled $C$. jejuni showed individual and discernible bacteria, approximately $4 \mu \mathrm{m}$ in length, under fluorescent microscopy (Fig. 2A). Similarly, intact GFP-labeled $C$. jejuni were evident in the house fly vomitus up to 4 hours after ingestion, but intact and individual bacteria became progressively more difficult to discern as they were degraded or digested over time (Fig. 2B-D). Although fluorescence was detected, this was associated with broken or digested and non-viable bacteria. No fluorescence of GFP-labeled C. jejuni was detected $\geq 8$ hours (Fig. 2E) after

This article is protected by copyright. All rights reserved. 
ingestion of $C$. jejuni and no GFP-labeled $C$. jejuni were found in control fly regurgitate at any time point.

Retention of viable C. jejuni in house fly vomitus and excreta

Fly vomitus and/or excreta on the inside of the microcentrifuge tube was found to contain viable $C$. jejuni up to $4 \mathrm{~h}$ after ingestion (Table 2). Forty percent of flies at $<1 \mathrm{~h}$ and $4 \mathrm{~h}$ were $C$. jejuni-positive. No viable $C$. jejuni was found $8-24 \mathrm{~h}$ following ingestion and all control flies were negative for bacterial growth.

\section{GI-tract subtracted library in response to bacterial ingestion}

We sequenced 386 independent clones from the $M$. domestica Gl-tract subtracted library in response to $C$. jejuni ingestion. Twenty-six clones (6.7\%) that either had inserts $<60$ bp in length or which had poor quality sequence were excluded from the analysis. In total, 109 clones (28.2\%) corresponded to unique EST sequences, which are described in more detail in Table S1. NCBI database searches using BLAST-X and BLAST-N resulted in 16 clones with no significant match, and 7 to hypothetical, uncharacterized, proteins deduced in silico from genome sequencing and annotation projects. Forty six (42.2\%) of the putative genes had more than one copy, and 27 (24.8\%) of these were highly redundant (more than 3 copies). Redundant clones were included in the functional analysis (Fig. 3) as this may reflect the importance of these genes in the physiology and immunity in the $\mathrm{Gl}$ tract of $M$. domestica in response to $C$. jejuni.

All identified genes were clustered into functional groups according to their putative biological function; binding, cytoskeleton, defence (immunity), metabolism, mitochondrial, protease inhibitor, protease/proteolysis, ribosomal, transcriptional/translational control, transport and other (Fig. 3). The majority of genes were found in the protease/proteolysis (15.0\%), transport (14.4\%), and metabolism (10.0\%) groups, with $6.9 \%$ of genes found in the defence (immunity) group. Some housekeeping genes (ribosomal, mitochondrial: $10.3 \%$ and $1.9 \%$, respectively), whose amplification is normally repressed, were also found in the library as has been reported in other SSH studies (Ursic-Bedoya \& Lowenberger, 2007; Barón et al., 2010). The genes associated with regulators of immunity included a putative eukaryotic translation initiation factor $4 \mathrm{E}$-binding protein (thor), a putative c-Jun $\mathrm{N}$-terminal kinase (JNK), and a putative serine protease of the Toll pathway (spheroide).

\section{Gene expression}

The temporal expression of selected AMP and immune-related transcripts in infected and control adult house fly GI tracts was compared. When comparing the putative immune-regulation

This article is protected by copyright. All rights reserved. 
genes, there was no significant change in the expression of JNK at any time point after ingestion (Fig. 4A) but Spheroide and thor demonstrated an early peak in expression at 2 hours of 2- and 5.5-fold, respectively, and their expression levels fell to control levels at all subsequent time points (Fig. 4B,C).

The expression levels of the different effector AMPs are shown in Figure 5. All AMPs show minimal changes in expression at $2 \mathrm{~h}$ post ingestion. Cecropin, defensin, and attacin all showed a large increase in expression by $4 \mathrm{~h}$ after ingestion, and a peak in expression at $8 \mathrm{~h}$ of 35-, 9-, and 24fold, respectively (Fig. 5A,B,D). Whereas attacin expression remained up-regulated at 12 and $24 \mathrm{~h}$, expression levels of cecropin and defensin fell to control levels by $12 \mathrm{~h}$. Diptericin demonstrated a 19-fold peak in expression at $4 \mathrm{~h}$ and remained up-regulated at all subsequent time points (Fig. $5 \mathrm{C}$ ). The digestive Lysozyme demonstrated no significant difference in mRNA expression at any timepoint after ingestion (Fig. 5E).

\section{Discussion}

Campylobacter jejuni has become one of the most common bacterial causes of gastroenteritis (WHO, 2013) and other sequelae such as acute and chronic gastrointestinal disease inflammatory bowel diseases (IBD), and colorectal cancer (Kaakoush et al., 2015a; Man, 2011). Bilions of dollars could be saved each year in the United States by eliminating this emerging disease (Buzby et al., 1997; Altekruse et al., 1999). Musca domestica is regarded as a principal insect vector of $C$. jejuni, yet we know relatively little of its role as an amplifying host. While data are available on house fly interactions with several bacteria, there are few available data on the molecular interactions between $C$. jejuni and the house fly and specifically how this relates to the epidemiology of campylobacteriosis. We investigated the period during which $C$. jejuni remains viable in house fly vomitus and excreta following the ingestion of ecologically-relevant doses of the bacterium to which house flies might be exposed as they forage and feed in animal manure (Bahrndorff et al., 2014a; Szalanski et al., 2004).

The bacterial load (CFU/mL) in the whole bodies of house flies was estimated at different time points post-ingestion. Because the house flies had been starved overnight, they all fed to repletion quickly. The effect of this food deprivation on other resident gut microbiota is unknown. The results show a large reduction in bacterial numbers within the first $8 \mathrm{~h}$ and no countable colonies were present 12-24 h after exposure (Fig. 1) as seen in previous studies (Skovgård et al., 2011). Campylobacter spp. may change morphology (become coccoidal) and exhibit poor growth when stressed (Mihaljevic et al., 2007; Cameron et al., 2012). We used serial dilutions of whole fly homogenates and it is possible that some component from the flies affected bacterial growth, although this has not been reported previously. Similar results have been reported for house flies infected with S. aureus (Nayduch et al., 2013) whereas some bacteria, Aeromonas hydrophilia, Aeromonas caviae, and Enterococcus faecalis have been reported to multiply within the house fly (Nayduch et al., 2002; McGaughey \& Nayduch, 2009; Doud \& Zurek, 2012). Aeromonas hydrophilia,

This article is protected by copyright. All rights reserved. 
A. caviae, and C. jejuni are Gram-negative bacteria whereas E. faecalis and S. aureus are Grampositive bacteria which indicates that the response, replication or not within the house fly, is not defined by class of bacteria. Indeed the response by the house fly may depend on the molecular patterns found on the surface of the bacteria. There may be significant differences in the lipopolysaccharides found on Gram-negative bacteria, and if this serves as the PAMP that activates the innate immune response of the house fly then we would expect to see differences in immune responses to these bacteria. Alternatively, the bacteria simply may have died due to an inhospitable environment in the Gl tract of the flies rather than a directed response by the innate immune system.

Visualization of house fly regurgitate using fluorescent microscopy demonstrated that $C$. jejuni was detectable in the vomitus up to 4 hours after ingestion. The bacteria, however, appear to be progressively degraded and digested over time (Fig. 2B-D), with no $C$. jejuni detected $\geq 8 \mathrm{~h}$ (Fig. $2 \mathrm{E})$. The fly vomitus and/or excreta collected from the holding tubes and cultured on CCDA plates indicated that material collected up to 4 hours after ingestion contained viable $C$. jejuni, but no viable bacteria were present on plates seeded with vomitus and/or excreta collected $\geq 8 \mathrm{~h}$ post exposure (Table 2). Although we did not distinguish between vomitus and faecal specks, it is most likely that vomitus was present prior to 4 hours and excreta later (Hewitt, 1914).

Several genes were up-regulated in house flies in response to the ingestion of $C$. jejuni, including several immune-responsive genes described in other SSH studies (Ursic-Bedoya \& Lowenberger, 2007; Barón et al., 2010). These include genes classified as immune regulators and effector genes. The putative immune regulatory genes included a putative eukaryotic translation initiation factor $4 \mathrm{E}$-binding protein (thor), a putative c-Jun $\mathrm{N}$-terminal kinase (JNK), and a putative serine protease of the Toll pathway (spheroide). There was an early increase in the expression of thor (Fig. 4C) similar to the response of Drosophila melanogaster to infection with Gram-negative bacteria (Rodriguez et al., 1996) and whose role is related to the early translational regulation of immune factors (Bernal \& Kimbrell, 2000). Spheroide also demonstrated an early pulse of expression (Fig. 4B) as might be expected in its putative role in the Toll signalling pathway that results in the expression of defensin (Hoffmann \& Reichhart, 2002). Both thor and spheroide fell to normal levels of expression by 4 hours (Fig. 4B,C). JNK is normally activated in response to Gram-negative bacteria lipopolysaccharides (Sluss et al., 1996; Wojda et al., 2004) and results in the release of AMPs (Mizutani et al., 2003), but in this study JNK expression did not change following ingestion. JNK upregulation may be very fast, within 10 min of infection, and peak expression levels are reported in < $60 \mathrm{~min}$ (Wojda et al., 2004), suggesting we may not have measured expression levels early enough. Even slight alterations in the expression of important signalling modulators could have major implications for host immunity with signalling cascades so intimately entwined (Tsakas \& Marmaras, 2010).

We examined the expression of insect AMPs commonly studied in other insects (Tzou et al., 2000; Hoffmann \& Reichhart, 2002; Liehl et al., 2006; Lemaitre \& Hoffmann, 2007). All AMPs tested (cecropin, defensin, attacin, and diptericin) other than lysozyme were up-regulated in response to $C$. jejuni ingestion (Fig. 5). Lysozymes can function as digestive or immune peptides, or as both (Lemos

This article is protected by copyright. All rights reserved. 
\& Terra, 1991; Ursic Bedoya et al., 2005; Ursic-Bedoya et al., 2008). The lysozyme studied here is a putative digestive enzyme (Nayduch et al., 2013; Bahrndorff et al., 2014b) and although not considered significant, there was an increase in lysozyme expression in C. jejuni-fed flies at 8 hours (1.8-fold; Fig. 5E). This fell below control fly lysozyme expression levels at 12 hours, and remained 3fold lower at 24 hours, which may highlight the fact that most bacteria had been degraded by this point and digestion was no longer required. There may be a constitutive level of lysozyme expression in house flies that may be altered during infection, and midgut infections may activate the systemic expression of other lysozymes and potentially other AMPs (Nayduch \& Joyner, 2013). It should be noted that many AMPs are expressed by hemocytes or the fat body and it is possible that some of these tissues may have adhered to the GI tract during dissection. If the genes we measured were expressed in adhering hemocytes then there must be a signalling mechanism to induce their expression in the body cavity while the bacteria remain in the Gl tract.

Although insects do not possess an adaptive immune system, they are able to discriminate among various classes of microorganisms, resulting in the induction of specific effector AMPs (Tzou et al., 2000). Our data demonstrate that the immune deficiency (IMD) pathway-associated AMPs (attacin, cecropin, diptericin) show a higher fold increase than the Toll pathway-associated defensin in C. jejuni-infected house flies (Fig. 5A-D). The IMD pathway is activated rapidly against Gramnegative bacteria, such as C. jejuni (Hoffmann \& Reichhart, 2002), and studies have demonstrated a specificity in the midgut response of $M$. domestica to Streptococcus pyogenes and Salmonella typhimurium (Chifanzwa, 2011). Attacin, diptericin, and cecropin, are strongly induced in the gut and Malpighian tubules of $D$. melanogaster following ingestion of infectious Gram-negative bacteria (Tzou et al., 2000; Liehl et al., 2006). In addition, our results demonstrate that the expression levels for defensin, attacin, and cecropin peak at 8 hours after infection, while diptericin expression peaks at 4 hours (Fig. 5A-D). A similar pattern of midgut expression levels of cecropin and defensin were seen in house flies infected with $E$. coli; but the expression levels and pattern for lysozyme differed from the current data (Fleming et al., 2014), although it is unclear if the same lysozyme gene was evaluated in the two studies. There were similarities in the pattern of expression of cecropin in house flies infected with $P$. aeruginosa (Joyner et al., 2013) and C. jejuni (this study) but differences in the pattern of expression of defensin and diptericin in these same studies. Diptericin is known to reach high concentration levels in the midgut, as well as in the proventriculus, an organ that acts as a valve between the oesophagus and the anterior midgut, and may provide an early barrier to eliminate ingested bacteria efficiently and rapidly (Liehl et al., 2006). In contrast, attacin and cecropin are primarily expressed in the midgut or Malpighian tubules (Tzou et al., 2000; Chifanzwa, 2011), which may explain why the peak expression in these AMPs follows that of diptericin.

The moderate up-regulation of some genes in the $C$. jejuni-exposed house flies may be due to the means by which we exposed flies to the bacteria. We exposed flies orally to ecologically-relevant doses, which differs from other studies in which bacteria were injected into the insect (Ursic-Bedoya

This article is protected by copyright. All rights reserved. 
\& Lowenberger, 2007, Wang et al., 2006). Injection into the hemocoel does not reflect natural conditions, but often is used to activate immune genes to the highest level for gene identification (Liehl et al., 2006). The expression levels of immune genes in the midgut of most insects are usually lower than levels seen in the hemocoel (fat body), and in many insects is down-regulated to ensure that essential microbial symbionts are not eliminated (Lopez et al., 2003, Ursic-Bedoya et al., 2011).

Our data suggest that $C$. jejuni remains viable in the vomitus and faecal specks of adult house flies for up to 4 hours. Subsequently, house fly excreta appear to be $C$. jejuni-free, possibly due to the activation of the immune and digestive responses in the alimentary tract of the flies, corroborating previous studies that found relatively short retention times of viable $C$. jejuni within the bodies of house flies (Skovgård et al., 2011; Bahrndorff et al., 2014b). There is no doubt that there are many other bacteria in the midguts of house flies, but we isolated $C$. jejuni on selective growth media and visualized the presence of GFP labeled $C$. jejuni using fluorescent microscopy to follow its development or elimination by the insect.

While these data highlight the role of house flies as mechanical, rather than biological amplifying vectors (Bahrndorff et al., 2014b; Gill, 2014), house flies continue to play a major role in the transmission of $C$. jejuni into and throughout poultry facilities. The data suggest that regurgitation and defecation of viable $C$. jejuni likely plays a significant part in disseminating the bacteria but that this window of opportunity for successful transmission is limited. Physical barriers that prevent the entry of house flies may ultimately provide the best means to reduce transmission of C. jejuni to poultry (Hald et al., 2007; Bahrndorff et al., 2013) and ultimately the incidence of campylobacteriosis in humans.

\section{Acknowledgments}

The authors are grateful to Dr. Gerhard Gries (Simon Fraser University) for providing M. domestica colonies, Dr. William Miller (USDA) for the GFP C. jejuni strain and Dr. Raul Ursic-Bedoya for technical support and advice. This research was funded in part by NSERC (RPG261940), the Canada Research Chairs program and a Michael Smith Scholar award to CL. SB was supported by a grant from the Danish Council for Independent Research, Technology and Innovation (Grant 11-116256).

\section{Disclosure}

The authors report no financial, scientific or intellectual conflicts of interest.

Supplementary Table S1. Novel ESTs.

This article is protected by copyright. All rights reserved. 


\section{References}

Altekruse, S.F., Stern, N.J., Fields, P.I. and Swerdlow, D.L. (1999) Campylobacter jejuni- an emerging foodborne pathogen. Emerging Infectious Diseases, 5, 28-35.

Ashburner, M., Ball, C.A., Blake, J.A., Botstein, D., Butler, H., Cherry, J.M., Davis, A.P., Dolinski, K., Dwight, S.S. and Eppig, J.T. (2000) Gene ontology: tool for the unification of biology. Nature genetics, 25, 25-29.

Bahrndorff, S., Garcia, A.B., Vigre, H., Nauta, M., Heegaard, P.M., Madsen, M., Hoorfar, J. and Hald, B. (2015) Intestinal colonization of broiler chickens by Campylobacter spp. in an experimental infection study. Epidemiology \& Infection, 143, 1-9.

Bahrndorff, S., Gill, C., Lowenberger, C., Skovgard, H. and Hald, B. (2014) The effects of temperature and innate immunity on transmission of Campylobacter jejuni (Campylobacterales: Campylobacteraceae) between life stages of Musca domestica (Diptera: Muscidae). Journal of Medical Entomology, 51, 670-677.

Bahrndorff, S., Rangstrup-Christensen, L., Nordentoft, S. and Hald, B. (2013) Foodborne disease prevention and broiler chickens with reduced Campylobacter infection. Emerging infectious diseases, 19, 425.

Barón, O.L., Ursic-Bedoya, R.J., Lowenberger, C.A. and Ocampo, C.B. (2010) Differential gene expression from midguts of refractory and susceptible lines of the mosquito, Aedes aegypti, infected with Dengue-2 virus. Journal of Insect Science, 10, 1-23.

Bernal, A. and Kimbrell, D.A. (2000) Drosophila Thor participates in host immune defense and connects a translational regulator with innate immunity. Proceedings of the National Academy of Sciences of the United States of America, 97, 6019-6024.

Boulanger, N., Bulet, P. and Lowenberger, C. (2006) Antimicrobial peptides in the interactions between insects and flagellate parasites. TRENDS in Parasitology, 22, 262-268.

Boulanger, N., Lowenberger, C., Volf, P., Ursic, R., Sigutova, L., Sabatier, L., Svobodova, M., Beverley, S.M., SpãßTh, G. and Brun, R. (2004) Characterization of a defensin from the sand fly Phlebotomus duboscqi induced by challenge with bacteria or the protozoan parasite Leishmania major. Infection and immunity, 72, 7140-7146.

This article is protected by copyright. All rights reserved. 
Boutros, M., Agaisse, H. and Perrimon, N. (2002) Sequential activation of signaling pathways during innate immune responses in Drosophila. Developmental cell, 3, 711-722.

Bulet, P., Hetru, C., Dimarcq, J.-L. and Hoffmann, D.L. (1999) Antimicrobial peptides in insects; structure and function. Developmental \& Comparative Immunology, 23, 329-344.

Buzby, J.C., Allos, B.M. and Roberts, T. (1997) The economic burden of Campylobacter-associated Guillain-Barré syndrome. Journal of Infectious Diseases, 176, S192-S197.

Cameron, A., Frirdich, E., Huynh, S., Parker, C.T. and Gaynor, E.C. (2012) Hyperosmotic stress response of Campylobacter jejuni. Journal of Bacteriology, 194, 6116-6130.

Carbon, S., Ireland, A., Mungall, C.J., Shu, S., Marshall, B. and Lewis, S. (2009) AmiGO: online access to ontology and annotation data. Bioinformatics, 25, 288-289.

Chifanzwa, R. (2011) House fly (Musca domestica L.) temporal and spatial immune response to streptococcus Pyogenes and Salmonella typhimurium: Role of pathogen density in bacterial fate, persistence and transmission,. MSc ed. Georgia Southern University.

Dang, X., Wang, Y., Huang, Y., Yu, X. and Zhang, W. (2010) Purification and characterization of an antimicrobial peptide, insect defensin, from immunized house fly (Diptera: Muscidae). Journal of Medical Entomology, 47, 1141-1145.

Doud, C.W. and Zurek, L. (2012) Enterococcus faecalis OG1RF:pMV158 survives and proliferates in the house fly digestive tract. Journal of Medical Entomology, 49, 150-155.

Ecdc, E. (2013) The European Union summary report on trends and sources of zoonoses, zoonotic agents and foodborne outbreaks in 2011. The European Food Safety Authority (EFSA) Journal, 11, 3129.

Efsa (2014) The European Union summary report on trends and sources of zoonoses, zoonotic agents and food-borne outbreaks in 2012. The European Food Safety Authority (EFSA) Journal, 12, 3547.

Efsa, E. (2011) Scientific opinion on Campylobacter in broiler meat production: control options and performance objectives and/or targets at different stages of the food chain. The European Food Safety Authority (EFSA) Journal, 9, 141.

This article is protected by copyright. All rights reserved. 
Fleming, A., Kumar, H.V., Joyner, C., Reynolds, A. and Nayduch, D. (2014) Temporospatial fate of bacteria and immune effector expression in house flies fed GFP-Escherichia coli 0157:H7. Medical \& Veterinary Entomology, 28, 364-371.

Gill, C. (2014) Investigating the vector competence of the house fly (Musca domestica) for Campylobacter jejuni. MSc thesis, Simon Fraser University, 116 pp.

Guan, T.Y. and Holley, R.A. (2003) Pathogen survival in swine manure environments and transmission of human enteric illness - a review. Journal of Environmental Quality, 32, 383392.

Hald, B., Skovgard, H., Pedersen, K. and Bunkenborg, H. (2008) Influxed insects as vectors for Campylobacter jejuni and Campylobacter coli in Danish broiler houses. Poultry Science, 87, 1428-1434.

Hald, B., Skovgard, H., Bang, D.D., Pedersen, K., Dybdahl, J., Jespersen, J.B. and Madsen, M. (2004) Flies and Campylobacter infection of broiler flocks. Emerging Infectious Diseases, 10, 14901492.

Hald, B., Sommer, H.M. and Skovgard, H. (2007) Use of fly screens to reduce Campylobacter spp. introduction in broiler houses. Emerging Infectious Diseases, 13, 1951.

Hewitt, G.C. (Ed.) (1914) The House-Fly. Cambridge University Press, London, UK.

Hoffmann, J.A. and Reichhart, J.M. (2002) Drosophila innate immunity: an evolutionary perspective. Nature Immunology, 3, 121-126.

Jacobs-Reitsma, W., Van De Giessen, A., Bolder, N. and Mulder, R. (1995) Epidemiology of Campylobacter spp. at two Dutch broiler farms. Epidemiology and Infection, 114, 413-421.

Joyner, C., Mills, M.K. and Nayduch, D. (2013) Pseudomonas aeruginosa in Musca domestica L.: temporospatial examination of bacteria population dynamics and house fly antimicrobial responses. PLOS ONE, 8, e79224.

Kaakoush, N.O., Castano-Rodriguez, N., Mitchell, H.M. and Man, S.M. (2015a) Global epidemiology of Campylobacter infection. Clinical Microbiology Review, 28, 687-720.

This article is protected by copyright. All rights reserved. 
Kaakoush, N.O., Deshpande, N.P., Man, S.M., Burgos-Portugal, J.A., Khattak, F.A., Raftery, M.J., Wilkins, M.R. and Mitchell, H.M. (2015b) Transcriptomic and proteomic analyses reveal key innate immune signatures in the host response to the gastrointestinal pathogen Campylobacter concisus. Infection and Immunity, 83, 832-845.

Kjærsgaard, A., Blanckenhorn, W.U., Pertoldi, C., Loeschcke, V., Kaufmann, C., Hald, B., Pagès, N. and Bahrndorff, S. (2015) Plasticity in behavioural responses and resistance to temperature stress in Musca domestica. Animal Behaviour, 99, 123-130.

Klein, M., Brown, L., Tucker, R.W., Ashbolt, N.J., Stuetz, R.M. and Roser, D.J. (2010) Diversity and abundance of zoonotic pathogens and indicators in manures of feedlot cattle in Australia. Applied Environmental Microbiology, 76, 6947-6950.

Kobayashi, M., Sasaki, T., Saito, N., Tamura, K., Suzuki, K., Watanabe, H. and Agui, N. (1999) Houseflies: not simple mechanical vectors of enterohemorrhagic Escherichia coli 0157:H7. American Journal of Tropical Medocaome \& Hygiene, 61, 625-629.

Leclerc, V. and Reichhart, J.M. (2004) The immune response of Drosophila melanogaster. Immunological Reviews, 198, 59-71.

Lemaitre, B. and Hoffmann, J. (2007) The host defense of Drosophila melanogaster. Annual Review of Immunology, 25, 697-743.

Lemos, F.J. and Terra, W.R. (1991) Properties and intracellular distribution of a cathepsin D-like proteinase active at the acid region of Musca domestica midgut. Insect Biochemistry, 21, 457-465.

Liang, Y., Wang, J.X., Zhao, X.F., Du, X.J. and Xue, J.F. (2006) Molecular cloning and characterization of cecropin from the housefly (Musca domestica), and its expression in Escherichia coli. Developmental \& Comparative Immunology, 30, 249-257.

Liehl, P., Blight, M., Vodovar, N., Boccard, F.D.R. and Lemaitre, B. (2006) Prevalence of local immune response against oral infection in a Drosophila/Pseudomonas infection model. PLoS Pathogens, 2, e56.

Livak, K.J. and Schmittgen, T.D. (2001) Analysis of relative gene expression data using real-time quantitative PCR and the $2^{\Delta \Delta C T}$ method. Methods, 25, 402-408.

This article is protected by copyright. All rights reserved. 
Lopez, L., Morales, G., Ursic, R., Wolff, M. and Lowenberger, C. (2003) Isolation and characterization of a novel insect defensin from Rhodnius prolixus, a vector of Chagas disease. Insect Biochemistry and Molecular Biology, 33, 439-447.

Lowenberger, C. (2001) Innate immune response of Aedes aegypti. Insect Biochemistry and Molecular Biology, 31, 219-229.

Lowenberger, C., Bulet, P., Charlet, M., Hetru, C., Hodgeman, B., Christensen, B.M. and Hoffmann, J.A. (1995) Insect immunity: Isolation of three novel inducible antibacterial defensins from the vector mosquito, Aedes aegypti. Insect Biochemistry and Molecular Biology, 25, 867873.

Lowenberger, C., Charlet, M., Vizioli, J., Kamal, S., Richman, A., Christensen, B.M. and Bulet, P. (1999) Antimicrobial activity spectrum, cDNA cloning, and mRNA expression of a newly isolated member of the cecropin family from the mosquito vector Aedes aegypti. Journal of Biological Chemistry, 274, 20092-20097.

Man, S.M. (2011) The clinical importance of emerging Campylobacter species. Nature Reviews Gastroenterology \& Hepatology, 8, 669-685.

Mcgaughey, J. and Nayduch, D. (2009) Temporal and spatial fate of GFP-expressing motile and nonmotile Aeromonas hydrophila in the house fly digestive tract. Journal of Medical Entomology, 46, 123-130.

Medzhitov, R. and Janeway, C.A., Jr. (1997) Innate immunity: impact on the adaptive immune response. Current Opin Immunology, 9, 4-9.

Mihaljevic, R.R., Sikic, M., Klancnik, A., Brumini, G., Mozina, S.S. and Abram, M. (2007) Environmental stress factors affecting survival and virulence of Campylobacter jejuni. Microbial Pathogenesis, 43, 120-125.

Miller, W.G., Bates, A.H., Horn, S.T., Brandl, M.T., Wachtel, M.R. and Mandrell, R.E. (2000) Detection on surfaces and in Caco-2 cells of Campylobacter jejuni cells transformed with new gfp, yfp, and cfp marker plasmids. Applied and Environmental Microbiology, 66, 5426-5436.

Mizutani, T., Kobayashi, M., Eshita, Y., Shirato, K., Kimura, T., Ako, Y., Miyoshi, H., Takasaki, T., Kurane, I. and Kariwa, H. (2003) Involvement of the JNK-like protein of the Aedes albopictus

This article is protected by copyright. All rights reserved. 
mosquito cell line, $\mathrm{C6} / 36$, in phagocytosis, endocytosis and infection of West Nile virus. Insect Molecular Biology, 12, 491-499.

Nayduch, D., Cho, H. and Joyner, C. (2013) Staphylococcus aureus in the house fly: temporospatial fate of bacteria and expression of the antimicrobial peptide defensin. Journal of Medical Entomology, 50, 171-178.

Nayduch, D. and Joyner, C. (2013) Expression of lysozyme in the life history of the house fly (Musca domestica L.). Journal of Medical Entomology, 50, 847-852.

Nayduch, D., Noblet, G.P. and Stutzenberger, F.J. (2002) Vector potential of houseflies for the bacterium Aeromonas caviae. Medical \& Veterinary Entomology, 16, 193-198.

Nazni, W.A., Luke, H., Wan Rozita, W.M., Abdullah, A.G., Sa'diyah, I., Azahari, A.H., Zamree, I., Tan, S.B., Lee, H.L. and Sofian, M.A. (2005) Determination of the flight range and dispersal of the house fly, Musca domestica (L.) using mark release recapture technique. Tropical Biomedicine, 22, 53-61.

Nichols, G.L. (2005) Fly transmission of Campylobacter. Emerging Infectious Diseases, 11, 361-364.

Pell, A.N. (1997) Manure and microbes: public and animal health problem? Journal of Dairy Science, 80, 2673-2681.

Petridis, M., Bagdasarian, M., Waldor, M.K. and Walker, E. (2006) Horizontal transfer of Shiga toxin and antibiotic resistance genes among Escherichia coli strains in house fly (Diptera: Muscidae) gut. Journal of Medical Entomology, 43, 288-295.

Rodriguez, A., Zhou, Z., Tang, M.L., Meller, S., Chen, J., Bellen, H. and Kimbrell, D.A. (1996) Identification of immune system and response genes, and novel mutations causing melanotic tumor formation in Drosophila melanogaster. Genetics, 143, 929-940.

Rosef, O. and Kapperud, G. (1983) House flies (Musca domestica) as possible vectors of Campylobacter fetus subsp. jejuni. Appllied Environmental Microbiology, 45, 381-383.

Sasaki, T., Kobayashi, M. and Agui, N. (2000) Epidemiological potential of excretion and regurgitation by Musca domestica (Diptera: Muscidae) in the dissemination of Escherichia coli 0157: $\mathrm{H7}$ to food. Journal of Medical Entomology, 37, 945-949.

This article is protected by copyright. All rights reserved. 
Schmittgen, T.D. and Livak, K.J. (2008) Analyzing real-time PCR data by the comparative $C_{T}$ method. Nature Protocols, 3, 1101-1108.

Scott, J.G., Warren, W.C., Beukeboom, L.W., Bopp, D., Clark, A.G., Giers, S.D., Hediger, M., Jones, A.K., Kasai, S. and Leichter, C.A., et al. (2014) Genome of the house fly, Musca domestica L., a global vector of diseases with adaptations to a septic environment. Genome Biology, 15, 466.

Shane, S.M., Montrose, M.S. and Harrington, K.S. (1985) Transmission of Campylobacter jejuni by the housefly (Musca domestica). Avian Diseases, 384-391.

Skovgård, H. and Jespersen, J.B. (2000) Seasonal and spatial activity of Hymenopterous pupal parasitoids (Pteromalidae and Ichneumonidae) of the house fly (Diptera: Muscidae) on Danish pig and cattle farms. Environmental Entomology, 630-637.

Skovgård, H., Kristensen, K. and Hald, B. (2011) Retention of Campylobacter (Campylobacterales: Campylobacteraceae) in the house fly (Diptera: Muscidae). Journal of Medical Entomology, 48, 1202-1209.

Sluss, H.K., Han, Z., Barrett, T., Davis, R.J. and Ip, Y.T. (1996) A JNK signal transduction pathway that mediates morphogenesis and an immune response in Drosophila. Genes \& Development, 10, $2745-2758$.

Szalanski, A.L., Owens, C.B., Mckay, T. and Steelman, C.D. (2004) Detection of Campylobacter and Escherichia coli $0157: \mathrm{H7}$ from filth flies by polymerase chain reaction. Medical \& Veterinary Entomology, 18, 241-246.

Tsakas, S. and Marmaras, V.J. (2010) Insect immunity and its signalling: an overview. Invertebrate Surviv Journal, 7, 228-238.

Tzou, P., Ohresser, S., Ferrandon, D., Capovilla, M., Reichhart, J.M., Lemaitre, B., Hoffmann, J.A. and Imler, J.L. (2000) Tissue-specific inducible expression of antimicrobial peptide genes in Drosophila surface epithelia. Immunity, 13, 737-748.

Ursic-Bedoya, R., Buchhop, J., Joy, J., Durvasula, R. and Lowenberger, C. (2011) Prolixicin: a novel antimicrobial peptide isolated from Rhodnius prolixus with differential activity against bacteria and Trypanosoma cruzi. Insect Molecular Biology, 20, 775-786.

This article is protected by copyright. All rights reserved. 
Ursic-Bedoya, R.J. and Lowenberger, C.A. (2007) Rhodnius prolixus: Identification of immune-related genes up-regulated in response to pathogens and parasites using suppressive subtractive hybridization. Developmental \& Comparative Immunology, 31, 109-120.

Ursic-Bedoya, R.J., Nazzari, H., Cooper, D., Triana, O., Wolff, M. and Lowenberger, C. (2008) Identification and characterization of two novel lysozymes from Rhodnius prolixus, a vector of Chagas disease. Journal of Insect Physiology, 54, 593-603.

Ursic Bedoya, R.J., Mitzey, A.M., Obraztsova, M. and Lowenberger, C. (2005) Molecular cloning and transcriptional activation of lysozyme-encoding cDNAs in the mosquito Aedes aegypti. Insect Molecular Biology, 14, 89-94.

Van De Giessen, A., Mazurier, S., Jacobs-Reitsma, W., Jansen, W., Berkers, P., Ritmeester, W. and Wernars, K. (1992) Study on the epidemiology and control of Campylobacter jejuni in poultry broiler flocks. Applied and Environmental Microbiology, 58, 1913-1917.

Vandesompele, J., De Preter, K., Pattyn, F., Poppe, B., Van Roy, N., De Paepe, A. and Speleman, F. (2002) Accurate normalization of real-time quantitative RT-PCR data by geometric averaging of multiple internal control genes. Genome Biology, 3, RESEARCH0034.

Wang, J.X., Zhao, X.F., Liang, Y.L., Li, L., Zhang, W., Ren, Q., Wang, L.C. and Wang, L.Y. (2006) Molecular characterization and expression of the antimicrobial peptide defensin from the housefly (Musca domestica). Cellular and Molecular Life Sciences CMLS, 63, 3072-3082.

Who (2013) The Global View of Campylobacteriosis. A Report of an Expert Consultation. World Health Organization, Geneva.

Wojda, I., Kowalski, P. and Jakubowicz, T. (2004) JNK MAP kinase is involved in the humoral immune response of the greater wax moth larvae Galleria mellonella. Archives of Insect Biochemistry and Physiology, 56, 143-154.

Zhong, M., Wang, X., Wen, J.F., Cai, J.F., Wu, C. and Aly, S.M. (2013) Selection of reference genes for quantitative gene expression studies in the house fly (Musca domestica L.) using reverse transcription quantitative real-time PCR. Acta Biochimica et Biophysica Sinica (Shanghai), 45, 1069-1073.

This article is protected by copyright. All rights reserved. 


\section{Figure Legends}

Figure 1. Mean number $( \pm \mathrm{SD})(\mathrm{CFU} / \mathrm{g})$ of Campylobacter jejuni enumerated from the whole

bodies of house flies at different time points after ingestion. The stock solution used for

infection was estimated to contain $2.10 \times 10^{9} \mathrm{CFU} / \mathrm{ml}$ of $C$. jejuni. All data points represent

five replicates of two individual flies per replicate.

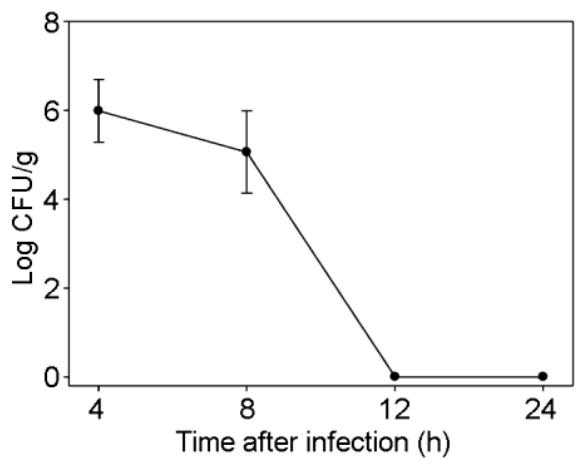

Figure 2. Visualization of GFP-labeled Campylobacter jejuni in the vomitus of adult house flies at different time points after ingestion using fluorescent microscopy at 1000x magnification and oil immersion. Panel a: Suspension of $C$. jejuni used for infection depicted here as a positive control; Panels b-e: Regurgitate visualized at $<1,2,4$, and $8 \mathrm{~h}$ after ingestion. No fluorescence was evident $\geq$ $8 \mathrm{~h}$ or in any of the control flies.

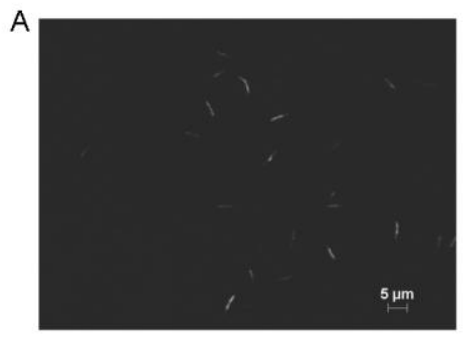

Infection suspension

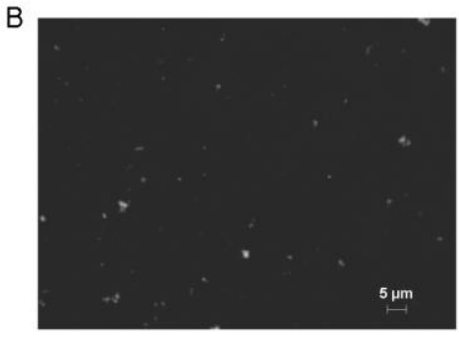

$<1 \mathrm{~h}$

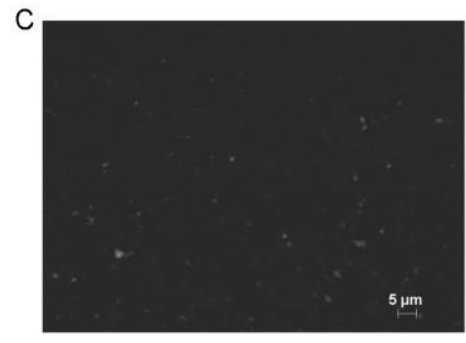

$2 \mathrm{~h}$

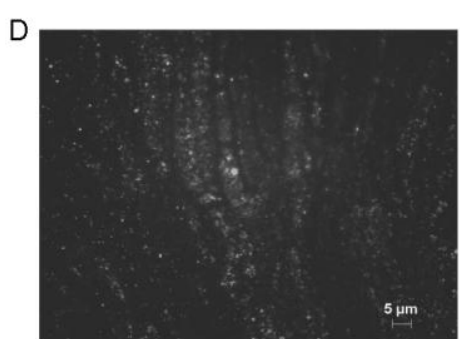

$4 \mathrm{~h}$

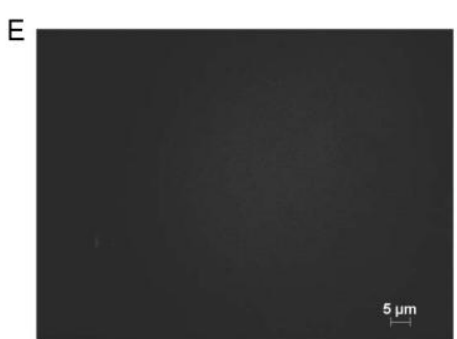

$8 \mathrm{~h}$

This article is protected by copyright. All rights reserved. 
Figure 3. Functional prediction and classification of differentially expressed ESTs in the GI tracts of adult house flies after ingesting Campylobacter jejuni. EST numbers include redundant clones and numerical superscripts represent the number of independent, unique, ESTs (109 total) excluding redundant clones. Novel ESTs were submitted to dbEST at the National Center for Biotechnology Information (NCBI) and assigned accession nos. 78910768-78911127 [GenBank: JZ545987JZ546346].

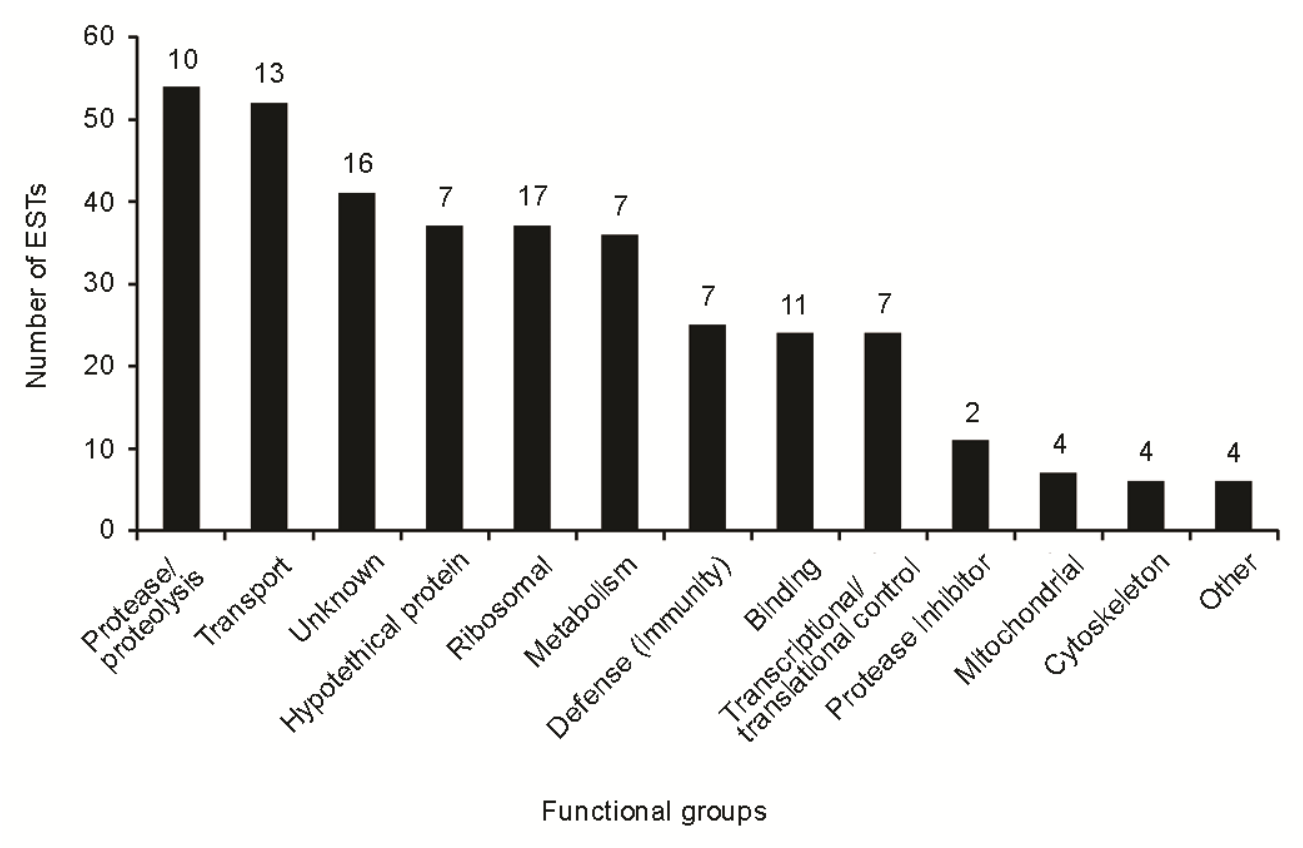

Figure 4. Expression levels (mean $+\mathrm{SE}$ ) of putative regulatory genes, JNK, spheroide and thor in the GI tracts of adult Musca domestica after ingesting Campylobacter jejuni.

Expression levels in control, non-infected, flies were arbitrarily set at 1 (grey bars) and the expression levels in infected flies (black bars) represent fold-differences from these controls. The graphs represent data collected from 2-3 independently generated cDNAs from three biological replicates with each sample run in duplicate. Expression levels were normalized with $\beta$-actin and GAPDH.

This article is protected by copyright. All rights reserved. 

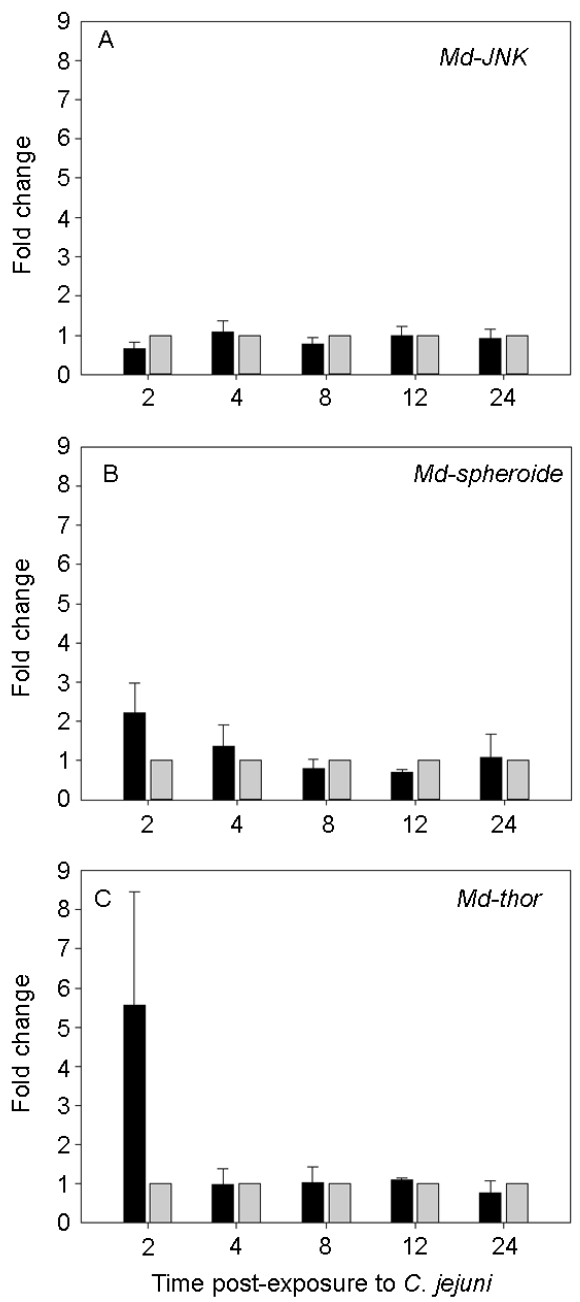

Figure 5. Expression levels (mean + SE) of selected effector antimicrobial peptides (cecropin, defensin, diptericin, attacin and lysozyme) in the GI tracts of adult Musca domestica after ingesting Campylobacter jejuni. Expression levels in control, non-infected, flies were arbitrarily set at 1 (grey bars) and the expression levels in infected flies (black bars) represent fold-differences from these controls. The results represent data collected from 2-3 independently generated cDNAs from three biological replicates with each sample run in duplicate. Expression levels were normalized with $\beta$-actin and GAPDH. The scales on the yaxes are different due to significant variation in expression levels of the different genes.

This article is protected by copyright. All rights reserved. 

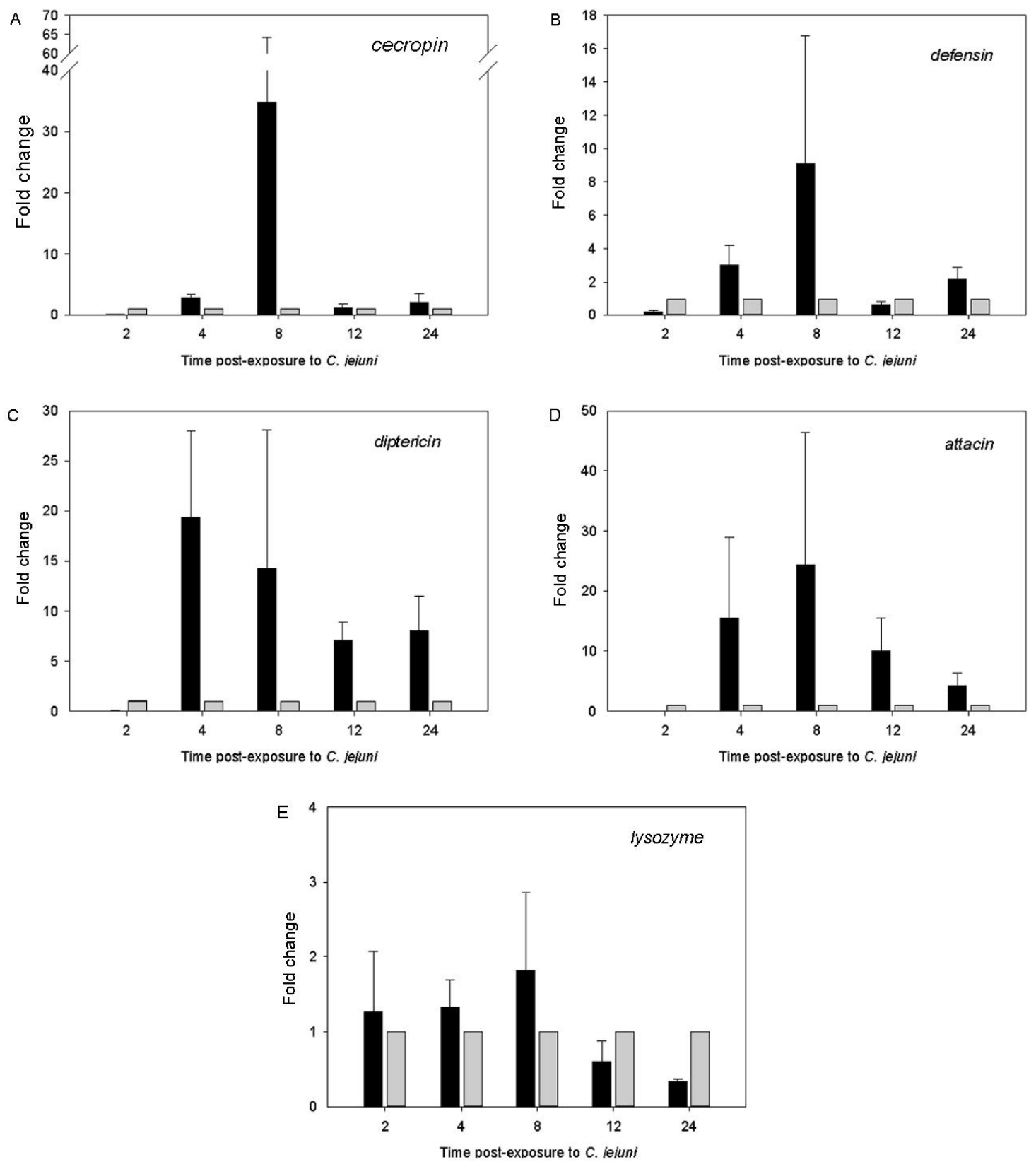

This article is protected by copyright. All rights reserved. 


\begin{tabular}{|c|c|c|c|}
\hline Gene & Primer sequence $\left(5^{\prime} \rightarrow 3^{\prime}\right)$ & Temp $^{*}\left({ }^{\circ} \mathrm{C}\right)$ & Amplicon size (bp) \\
\hline \multicolumn{4}{|l|}{ GAPDH } \\
\hline $\mathrm{F}$ & ACA ACG AAT TCG GTT ACT CC & 52.6 & 219 \\
\hline $\mathrm{R}$ & CCT GTC TGA TGA TGT GCG & 53.3 & \\
\hline \multicolumn{4}{|l|}{$\beta$-actin } \\
\hline $\mathrm{F}$ & GGT GTC ATG GGT TGG TAT GGG AC & 59.8 & 225 \\
\hline $\mathrm{R}$ & ACG ATT AGC CTT GGG ATT CAA TGG G & 59.2 & \\
\hline \multicolumn{4}{|l|}{ defensin } \\
\hline $\mathrm{F}$ & TGT CGC TGT TTT CTT GGC & 53.6 & 254 \\
\hline $\begin{array}{c}\mathrm{R} \\
\text { cecropin }\end{array}$ & CAA ACA CAA ACA CCT TTG CC & 53.2 & \\
\hline $\mathrm{F}$ & CTT GGC TGT TTG CAT TGG & 52.5 & 99 \\
\hline $\begin{array}{c}\mathrm{R} \\
\text { attacin }\end{array}$ & TTG AAT TGT AGC ATC GCG & 50.7 & \\
\hline F & TGG TCC TGT AAC CAG AGG AG & 55.7 & 226 \\
\hline \multicolumn{4}{|l|}{ diptericin } \\
\hline $\mathrm{F}$ & GCT CTA AGT GCC GCT CTT GTG G & 60.3 & 240 \\
\hline $\mathrm{R}$ & CGC CAC GGT AAT CAG GAC GAC & 60.2 & \\
\hline \multicolumn{4}{|l|}{ lysozyme } \\
\hline $\mathrm{F}$ & CAA CGG CCG TTT CTC CTA C & 56 & 137 \\
\hline $\mathrm{R}$ & ACT TCC AGG TGG ACC AGG C & 59.8 & \\
\hline \multicolumn{4}{|l|}{ Md-JNK } \\
\hline $\mathrm{F}$ & AGC TAC ATT CAT GTT TGG TAT GAC & 53.2 & 163 \\
\hline $\mathrm{R}$ & CAT TGG TAT TAT TAC TGG TAT GGG & 51.1 & \\
\hline \multicolumn{4}{|c|}{$\begin{array}{c}\text { Md- } \\
\text { spheroide }\end{array}$} \\
\hline $\mathrm{F}$ & GCA AGA ATG CTT ACA GTG CC & 54.6 & 214 \\
\hline $\mathrm{R}$ & ACT ACA ACA GAT TGA ATC CAG G & 52.4 & \\
\hline \multicolumn{4}{|l|}{ Md-thor } \\
\hline $\mathrm{F}$ & ATT CCG CAA GTG TGT GCC & 56.3 & 134 \\
\hline $\mathrm{R}$ & GGA GGA AGC ACG GTG TAT AG & 54.8 & \\
\hline
\end{tabular}

*Melting temperature

Table 1. Primers used in real time quantitative PCR of selected housekeeping genes, AMPs and immune-regulatory genes in Musca domestica.

Table 2. The retention of viable Campylobacter jejuni in the excreta and vomitus of Musca domestica following ingestion

This article is protected by copyright. All rights reserved. 


\begin{tabular}{cc}
\hline $\begin{array}{c}\text { Time After } \\
\text { Infection (h) }\end{array}$ & $\begin{array}{c}\text { Number of C. jejuni- } \\
\text { Positive Flies }\end{array}$ \\
\hline$<1$ & $2 / 5(40 \%)$ \\
2 & $1 / 5(20 \%)$ \\
4 & $2 / 5(40 \%)$ \\
8 & $0 / 5(0 \%)$ \\
12 & $0 / 5(0 \%)$ \\
24 & $0 / 5(0 \%)$ \\
\hline
\end{tabular}

This article is protected by copyright. All rights reserved. 